\title{
Thoughts and Approaches of Incorporating Chinese Traditional Culture into College Ideological and Political Education
}

\author{
Zhou Jufang \\ Weinan Normal University, Weinan, Shaanxi, 714000
}

Keywords: Chinese Traditional Culture, Higher Education, Ideological and Political Education

\begin{abstract}
After thousands of years of accumulation and precipitation, Chinese traditional culture contains a systematic and systematic educational theory with national characteristics. The university is the frontier of dissemination of China's ideology, the influence of traditional culture on the ideological and political education system in universities is more and more big, the traditional culture of ethical value orientation, emphasizing the unity of morality. Therefore, the ideological and political education should be rooted Chinese traditional culture, into the essence of traditional culture in higher education, higher talent cultivation optimization of morality. On the basis of the connotation and significance of Chinese traditional culture in China, the article puts forward the strategy of permeating Chinese traditional culture in Ideological and political education in Colleges and universities.
\end{abstract}

\section{Introduction}

China has a history of cultural development for thousands of years, and the traditional culture that has been handed down from generation to generation is a unique and unique essence of thought that other cultural ideas can not replace. It will exert profound influence on all social strata and fields, and also has strong educational function. It is the great achievement of the spiritual value of the stable value orientation and the way of thinking. In the course of the development of human civilization in the world, the traditional culture of our country has formed its own distinctive features through the influence of historical conditions, natural environment and other factors.

\section{The Connotation of Chinese Traditional Culture}

The so-called traditional culture refers to the formation of keep long history of development in a country, in the nation, with a stable form of culture, which is rich in content, including idea, multiple aspects of mode of thinking, value orientation, life style, rites, customs, religion, literature and art. Chinese traditional culture is a unique culture of the Chinese nation. Its development is based on Confucianism, including other ideological and cultural contents. Colleges and universities are the main positions of ideological and political education. Integrating excellent Chinese traditional culture in ideological and political education can not only improve college students' personality and cultivate their noble equipment, but also enrich their ideological background and promote their overall quality [1-2]. In a sense, Chinese traditional culture is the source and foundation of Ideological and political education system. We should cultivate contemporary college students' patriotic spirit of "taking the world as their responsibility", and guide them to form the moral training method of carefully alone province and enhance their sense of national responsibility. And the function of education is the own attribute of culture, and the traditional Chinese culture is the embodiment of the function of Ideological and political education. The essence of traditional culture has always been the carrier of education and inheritance in the history of history, and it is also a summary of the Chinese people's cognition of the function of culture and education. 


\section{The Value of Traditional Culture in Ideological and Political Education in Colleges and Universities}

Under the impact of various foreign cultures, the role of traditional culture in the ideological and political education in Colleges and universities is more valuable. Its main educational values are embodied in the following aspects:

First of all, strengthen college students' sense of identity to the socialist core value system. The core value system of socialism is the soul of building a harmonious socialist society, while Chinese traditional culture is the source and foundation of the socialist core value system, which contains the essence of Chinese traditional culture. Therefore, integrating traditional culture into Ideological and political education in colleges and universities can help students make full use of cultural carriers and cultural platforms, and enhance their cognition of the socialist core value system [3]. Secondly, to improve the humanistic spirit of college students. Under the new situation and new environment, China's higher education has been given new responsibilities and missions. Universities are no longer a purely cultural traditional organization, but also a strategic base for cultural innovation, so as to cultivate the forefront position of humanistic spirit and knowledge economy. In this process, human resources are the important factors to ensure the authenticity, fresh activity and infectivity of the ideological and political education. Again, strengthen the penetration of Ideological and political education. At present, the ideological and political education in Colleges and universities will affect the values of college students, the world outlook and the outlook on life to some extent. Influenced by various subjective factors and objective factors, the mode of Ideological and political education in Colleges and universities is too conservative and rigid, which is seriously divorced from the real society, which can not guarantee the educational effect. The organic combination of traditional culture and ideological and political education provides a new path to reform the ideological and political education, with strong cultural penetration and wide influence [4]. When students receive the education of traditional culture, their learning enthusiasm and initiative are also fully stimulated, thus improving the effectiveness of Ideological and political education. Finally, it helps college students to form values that are adaptable to society. The fundamental purpose of Ideological and political education is to cultivate the students the correct values, while in Chinese traditional culture contains abundant moral values, which is advocated in modern society values, including philosophy, scientific spirit and humanistic spirit, can promote students' correct value orientation itself.

\section{The Strategy of Integrating Chinese Traditional Culture into Ideological and Political Education in Colleges and Universities}

In the process of Ideological and political education in Colleges and universities, Chinese traditional culture can be permeated from the following aspects:

\subsection{Optimizing the environment of Ideological and Political Education}

Learning environment will exert a subtle influence on students' learning behavior and learning initiative. To create a good learning atmosphere of traditional culture is of great significance to cultivate college students' traditional cultural literacy and form the world outlook and values based on traditional ecological culture. Therefore, the society, the school, the family and other aspects should be joined together to create a good ideological and political education environment for the students to infiltrate the traditional culture. Colleges and universities can give full play to the role of traditional buildings in their own schools, and strengthen traditional culture propaganda in traditional buildings, classrooms, canteens, squares and other places, so that students can always be influenced by traditional culture in daily life and learning [5]. We should carry out related theme activities, such as Dragon Boat Festival and Mid-Autumn Festival, to improve the vividness and vividness of traditional culture and education, stimulate students' interest in learning, and make traditional culture play a good role in students' traditional Chinese culture. The development of modern information technology provides a good opportunity for the spread of Chinese traditional 
culture. Internet technology has improved the convenience of learning and communication between people. Traditional culture can also take the Internet as the platform, give full play to the important role of modern information technology, and improve the vividness, flexibility and image of traditional culture and education. In addition, the teacher should closely cooperate with the parents of the students, and actively guide the parents in the family to create an atmosphere of good traditional culture education, to encourage parents to actively participate in social activities, through words and deeds set a good example for the students [6-7].

\subsection{Infiltration of traditional culture in the teaching materials of Ideological and Political Education}

Classroom teaching is the main way to ensure the effectiveness of Ideological and political education. We must infiltrate traditional culture into Ideological and political education, and integrate traditional culture into teaching materials. First, the relevant contents of traditional culture are added to the teaching materials of Ideological and political education. The ideological and political courses in Colleges and universities in China mainly include ideological and moral cultivation and legal basis, Mao Zedong thought and the theoretical system of socialism with Chinese characteristics, the basic principles of Marx and the outline of modern Chinese history. On this basis, a variety of elective courses can be set up so that students should learn to choose independently according to their own personal interests. For example, many colleges and universities now offer "traditional culture" courses such as disciple rules, which not only enable students to expand their knowledge, but also have high ideological and moral qualities. Secondly, it integrates the related content of traditional culture in the teaching plan. Teachers can try to design school-based courses in Ideological and political education, such as "classic reading" and other courses [8]. In the classroom, we should guide the reading of Chinese classics, how to normalize the writing of Chinese characters, and teach traditional Chinese etiquette and folk culture, so as to enable students to learn more about traditional culture. In addition, some traditional culture scholars can be invited to open traditional culture classes, including celebrities, inheritors of intangible cultural heritage and so on, so that students can understand the essence of traditional culture. The students have a more thorough, detailed and systematic understanding of the Chinese traditional culture, and enhance their national pride and the sense of the traditional culture.

\subsection{The method of enriching the ideological and Political Education}

The educational process of Chinese traditional culture is not a process of instillation, but a process of infiltration. Therefore, it is necessary to enrich the methods of Ideological and political education. On the one hand, it is necessary to integrate the content of traditional culture into the social practice of college students. Social practice is an important way for college students to understand the society and experience life. In social practice, we can fully excavate the historical resources and the resources of historic sites, such as museums, exhibition galleries, cultural sites, scenic spots and historical sites. In order to enhance the cultural identity and cultural confidence of college students, this kind of place should be used as an educational base. In the school, we can organize traditional culture associations of college students to give full play to students' autonomy and initiative [9-10]. After holidays, after school, students are encouraged to participate in social surveys and public welfare projects, so that they can touch the society through multiple channels and feel the strength of traditional culture. The integration of traditional culture education in college students' social practice, can make it more profound understanding of the modern value of traditional culture and spiritual connotation, which gradually grow into excellent traditional cultural heritage, promote and spread, become conscious of the innovation and development of traditional culture promoters. On the other hand, the individual should be encouraged to teach students in accordance with their aptitude. Every student in different environment and different characteristics, there are differences in learning the behavior of learning attitude, therefore, the ideological and political education and other disciplines of education, should follow the principle of individualized, avoid all. Though influenced by objective factors, it is impossible to carry out education for every specific educational object, but we need to subdivide education groups, improve specific group 
education pertinence, so as to improve teaching effect [11].

\subsection{Improving teachers' traditional cultural accomplishment}

One is to strengthen the academic teachers' study on the traditional culture and further strengthen their theoretical basis. In order to meet the needs of students for understanding various kinds of traditional culture, university teachers must strictly absorb themselves on the basis of existing knowledge reserves, absorb other traditional excellent cultural knowledge, enrich their knowledge reserves, and improve their ideological and political education skills. The two is to cultivate the backbone teachers of traditional culture and culture. To improve college students' Ideological and political education level, colleges and universities should regularly select part of backbone teachers qualified to participate in the training of traditional culture, so that it could continue to expand cultural horizons, improve the comprehensive quality of culture, so that these teachers can really carry out the ideological and political theory teaching in the professional schools of traditional culture, so as to improve the efficiency of Ideological and political education. Because teachers' moral quality and life style will have an impact on students. Therefore, colleges and universities should strictly enforce teachers' moral self-discipline and stick to professional ethics, so that they can truly learn moral character from teachers.

\section{Conclusion}

Chinese traditional culture contains rich and profound spiritual value. After thousands of years of deduction and abandonment, the influence of traditional culture has been involved in every corner of society. In the ideological and political education of colleges and universities, we should fully understand the important significance of traditional culture, change the educational concept and optimize the education method. In the ideological and political education work, we should infiltrate the excellent traditional Chinese culture and give full play to the educational value of traditional culture, so that more students can receive the edification and education of traditional culture and constantly improve their sense of social responsibility. Strengthen the spirit of patriotism, improve its ideological and political quality in an all-round way, so as to enhance the cohesion and centrality of the Chinese nation. Of course, the organic combination of traditional culture and the ideological and political education in Colleges and universities is a systematic, persistent work, needs the joint efforts of various departments, the ideological and political education workers must continue to study, in the follow-up work to continue to explore, continue to practice, to find a dominant education and recessive education combined, the combination of the traditional education and modern education of Ideological and political education way.

\section{References}

[1] Zhang A, Marxism S O. Probe into college ideological and political education incorporating college campus culture in the new media environment[J]. Journal of Fujian University of Technology, 2016.

[2] Chen Y, University L. The integration of Chinese excellent traditional culture in ideological and political education in colleges and universities[J]. Journal of Jiamusi Vocational Institute, 2017.

[3] Wang C Q, Zhu S Q. Research on the Integration of Chinese Excellent Traditional Culture into College Students' Ideological and Political Education[J]. Journal of Hubei Correspondence University, 2017.

[4] ZHAO Hong. Significance of Chinese Traditional Culture Education in College Ideological and Political Work[J]. Journal of Huaihai Institute of Technology (Humanities \& Social Sciences Edition), 2017, 24(1):41-46.

[5] Jin Y Y, University J N. Thoughts on the Cohesion of Excellent Traditional Culture into the Ideological and Political Education for College Students[J]. Journal of Hubei Correspondence 
University, 2017.

[6] Kang L, University J M. The Value and Realization of Chinese Excellent Traditional Culture in the Ideological and Political Education of College Students[J]. Future \& Development, 2017.

[7] Wang Y, Jin X U. On the Application of Traditional Chinese Culture in Contemporary Ideological and Political Education of Higher Vocational and Technical Colleges[J]. Journal of Anhui Vocational \& Technical College, 2016.

[8] Yu W. Analysis of Chinese Excellent Traditional Culture Functioning in Ideological and Political Education in Colleges and Universities[J]. Theory Horizon, 2017.

[9] Chen J, Department S A, University H. On the Value of the Silk Road Spirit to College Ideological and Political Education[J]. Journal of College Advisor, 2017.

[10] Li H, Liu W, Marxism S O, et al. On Coordinate-type Practice Teaching for Ideological and Political Education in the Universities Run by Local Government[J]. Journal of Jixi University, 2016.

[11] Jianli X U, Zhu D, Polytechnic J. Establishing Synergistic Educational Mechanisms in Ideological and Political Education with Higher Vocational Educational Features[J]. Journal of Liaoning Agricultural Technical College, 2017. 